OPEN ACCESS

Edited by:

Jin Sun,

Ocean University of China, China

Reviewed by:

Genki Kobayashi,

Kyoto University, Japan

Jian-Wen Qiu,

Hong Kong Baptist University,

Hong Kong

Didier Alain Jollivet,

Centre National de la Recherche

Scientifique, Center for the National Scientific Research (CNRS), France

*Correspondence: Yadong Zhou yadong_zhou@sio.org.cn

Specialty section: This article was submitted to

Marine Evolutionary Biology, Biogeography and Species Diversity,

a section of the journal

Frontiers in Marine Science

Received: 19 February 2021

Accepted: 20 April 2021

Published: 26 May 2021

Citation:

Han Y, Zhang D, Wang C and

Zhou Y (2021) Out of the Pacific: A New Alvinellid Worm (Annelida: Terebellida) From the Northern Indian

Ocean Hydrothermal Vents.

Front. Mar. Sci. 8:669918.

doi: 10.3389/fmars.2021.669918

\section{Out of the Pacific: A New Alvinellid Worm (Annelida: Terebellida) From the Northern Indian Ocean Hydrothermal Vents}

\author{
Yuru Han ${ }^{1}$, Dongsheng Zhang ${ }^{1,2,3}$, Chunsheng Wang ${ }^{1,2,3,4}$ and Yadong Zhou ${ }^{1,2 *}$ \\ ${ }^{1}$ Key Laboratory of Marine Ecosystem Dynamics, Second Institute of Oceanography, Ministry of Natural Resources, \\ Hangzhou, China, ${ }^{2}$ Southern Marine Science and Engineering Guangdong Laboratory, Zhuhai, China, ${ }^{3}$ School \\ of Oceanography, Shanghai Jiao Tong University, Shanghai, China, ${ }^{4}$ State Key Laboratory of Satellite Ocean Environment \\ Dynamics, Hangzhou, China
}

Alvinellids have long been considered to be endemic to Pacific vents until recent discovery of their presence in the Indian Ocean. Here, a new alvinellid is characterized and formally named from recently discovered vents, Wocan, and Daxi, in the northern Indian Ocean. Both morphological and molecular evidences support its placement in the genus Paralvinella, representing the first characterized alvinellid species out of the Pacific. The new species, formally described as Paralvinella mira n. sp. herein, is morphologically most similar to Paralvinella hessleri from the northwest Pacific, but the two species differ in three aspects: (1), the first three chaetigers are not fused in P. mira n. sp., whereas fused in P. hessleri; (2), paired buccal tentacles short and pointed in $P$. mira but large and strongly pointed in $P$. hessleri; (3), numerous slender oral tentacles ungrouped in $P$. mira but two groups in $P$. hessleri. Phylogenetic inference using the concatenated alignments of the cytochrome c oxidase I (COI), 16S rRNA and $18 \mathrm{~S}$ rRNA genes strongly supports the clustering of $P$. mira with two West Pacific congeners, $P$. hessleri and an undescribed species (Para/vinella sp. ZMBN). The resulting Indian/West Pacific lineage suggests a possible invasion into the Indian Ocean from the West Pacific. This is the third polychaete reported from Wocan hydrothermal field. Among the three species, two including P. mira and Hesiolyra heteropoda (Annelida:Hesionidae) are present in high abundance, forming an alvinellids/hesionidsdominated polychaete assemblage distinct from that at all other Central Indian Ridge and Southwest Indian Ridge vents. Thus, this study expands our understanding of alvinellid biogeography beyond the Pacific, and adds to the unique biodiversity of the northern Indian Ocean vents, with implications for biogeographic subdivision across the Indian Ocean ridges.

Keywords: Paralvinella, northern Indian Ocean, deep sea, hydrothermal vent, new species

\section{INTRODUCTION}

Deep-sea hydrothermal vents are extreme habitats rich in energy and reduced matters, which support flourished chemosynthesis-based ecosystems and form biodiversity hotspots along the global spreading ridge systems (Van Dover, 2000). One of the most notable features of these vent communities is that they mainly comprise vent endemic fauna, which are not in any other 
habitats (Wolff, 2005). One of such typical examples is the vent endemic Alvinellidae (Annelida) Desbruyères and Laubier (1982), whose members are notable for their proximity to the fluid sources in hydrothermal vents and excellent adaptations to an extremely high temperature gradient (Jollivet and Hourdez, 2020).

A total of 12 alvinellid species have so far been described and assigned to two genera, Alvinella and Paralvinella. All of them are only known from Pacific hydrothermal vent fields, with the two Alvinella species (Alvinella pompejana Desbruyères and Laubier, 1980 and Alvinella caudata Desbruyères and Laubier, 1986) and three Paralvinella species (Paralvinella grasslei Desbruyères and Laubier, 1982, Paralvinella bactericola Desbruyères and Laubier, 1991 and Paralvinella pandorae irlandei Desbruyères and Laubier, 1986) reported from the East Pacific Rise (EPR) and Guaymas vent fields, four from the northeast Pacific (Paralvinella palmiformis Desbruyères and Laubier, 1986, Paralvinella pandorae pandorae Desbruyères and Laubier, 1986, Paralvinella dela Detinova, 1988 and Paralvinella sulfincola Desbruyères and Laubier, 1993), two from the southwest Pacific vent ecosystems (Paralvinella fijiensis Desbruyères and Laubier, 1993 and Paralvinella unidentata Desbruyères and Laubier, 1993), and one from the Marianas back-arc spreading center and the Okinawa Trough (Paralvinella hessleri Desbruyères and Laubier, 1989). These worms usually form dense aggregations on varied hard substrata, including chimney walls, basaltic cracks with venting fluids and siboglinid tubes (Tunnicliffe et al., 1993; Desbruyères et al., 1994; Hurtado et al., 2004). Although hydrothermal vent organisms usually show a high degree of regional endemism (Rogers et al., 2012), a family endemic to the Pacific vents is still rare. However, the view on this alvinellid biogeographic pattern is challenged by recent discovery of alvinellids in Indian Ocean vents.

Early investigations at Kairei and Edmond vent fields on the Central Indian Ridge (CIR) reported "notable absence" of alvinellids as one of the features that distinguish them from their Pacific counterparts (Van Dover et al., 2001). Investigations in vent fields on the Southwest Indian Ridge (SWIR) (e.g., Longqi and Tiancheng vent fields) and Southeast Indian Ridge (SEIR) (Plegia vent field) also found no signs of such worms (Copley et al., 2016; Zhou et al., 2018; Gerdes et al., 2019). However, at the Solitaire field over $800 \mathrm{~km}$ north of Kairei hydrothermal field, a deep-seabed image captured by the HumanOccupied Vehicle (HOV) Shinkai 6500 surprisingly revealed a small patch of alvinellid worms (taxonomically unresolved at general level) associated with the scaly foot snail, Chrysomallon squamiferum Chen et al. (2015), representing the first report of such worms outside the Pacific (Nakamura et al., 2012). In 2017, we collected alvinellid specimens from two vent sites, Daxi and Wocan on the Carlsberg Ridge (CR) in the northwest Indian Ocean. These alvinellids were abundant in the Wocan field, but were not commonly seen in the Daxi field (Wang et al., 2021). Due to the very late discovery of the first active deep-sea hydrothermal vent on the Carlsberg Ridge (almost 15 years after locating the first vent in the Indian Ocean) (Wang et al., 2017), little is known about the diversity of macrobenthos inhabiting the northern Indian
Ocean vents, with only a rough description of Daxi vent community at around $6^{\circ} 48^{\prime} \mathrm{N}$ (Wang et al., 2021). Most of the taxa are undescribed, except for three new species of polychaetes (Zhou et al., 2019; Wang et al., 2020). Since the alvinellid-dominated polychaete assemblage might be unique to the northwest Indian Ocean vents, identifying these alvinellid species and determining their phylogenetic relationships with their Pacific Ocean relatives will enhance our understanding of the divergence history and diversity of this family of vent endemic polychaetes.

An early study using allozyme recovered Alvinella and Paralvinella as two monophyletic groups (Jollivet et al., 1995). Based on DNA data, recent molecular phylogenetic studies recovered Alvinellidae as a monophyletic clade, while Paralvinella is a paraphyletic genus with the sequenced species split into two lineages (Vrijenhoek, 2013; Stiller et al., 2020). One Paralvinella lineage is composed of a pair of sibling geographic species, $P$. pandorae irlandei in the northeast Pacific and P. pandorae pandorae on the EPR; The other, comprising P. fijiensis (southwest Pacific), P. sulfincola (northeast Pacific), P. grasslei (EPR) and P. palmiformis (northeast Pacific), forms a clade with the Alvinella lineage, and this clade is sister to the $P$. pandorae lineage (Stiller et al., 2020). To address the issue of paraphyletic status of Paralvinella, Stiller et al. (2020) referred the P. pandorae lineage to Nautalvinella Desbruyères and Laubier, 1993 based on a combined multigene and morphological dataset, which was originally a subgenus in Paralvinella (Desbruyères and Laubier, 1993). Although there are three pairs of sibling geographic species ( $P$. palmiformis/P. grasslei, $P$. pandorae pandorae/P. pandorae irlandei, and $P$. dela/bactericola), no sequences from the remaining four Paralvinella species to fully resolve the within-familial phylogeny and biogeographic pattern in the Pacific (Jollivet and Hourdez, 2020). The discovery of alvinellids in the Indian Ocean has raised questions on alvinellid phylogeny and biogeography beyond the Pacific: (1) are the Indian Ocean alvinellids new to science?, (2) do they represent a distinct lineage or not?, and (3) how may this Indian lineage contribute to a better understanding of the biogeography of alvinellids. Aiming to answer these questions, we characterize these alvinellids with a combined morphological and genetic approach.

\section{MATERIALS AND METHODS}

\section{Collection and Preservation}

During the DY38 cruise in March 2017, alvinellid materials were collected from Wocan and Daxi vent fields on the Carlsberg Ridge in the northwest Indian Ocean (Figure 1). The samples were collected at venting sites by HOV Jiaolong equipped with a 7 -function manipulator. Over 50 alvinellid specimens from Wocan field were picked out from membranous tubes covered by coarse mineral grains and cemented to the surface of massive pyrites (Figure 2). In addition, two individuals were picked out from residues retained on a sieve after washing chimney fragments. After collection, samples were preserved in 95-100\% $(\mathrm{v} / \mathrm{v})$ ethanol. Type specimens were deposited in the Repository 


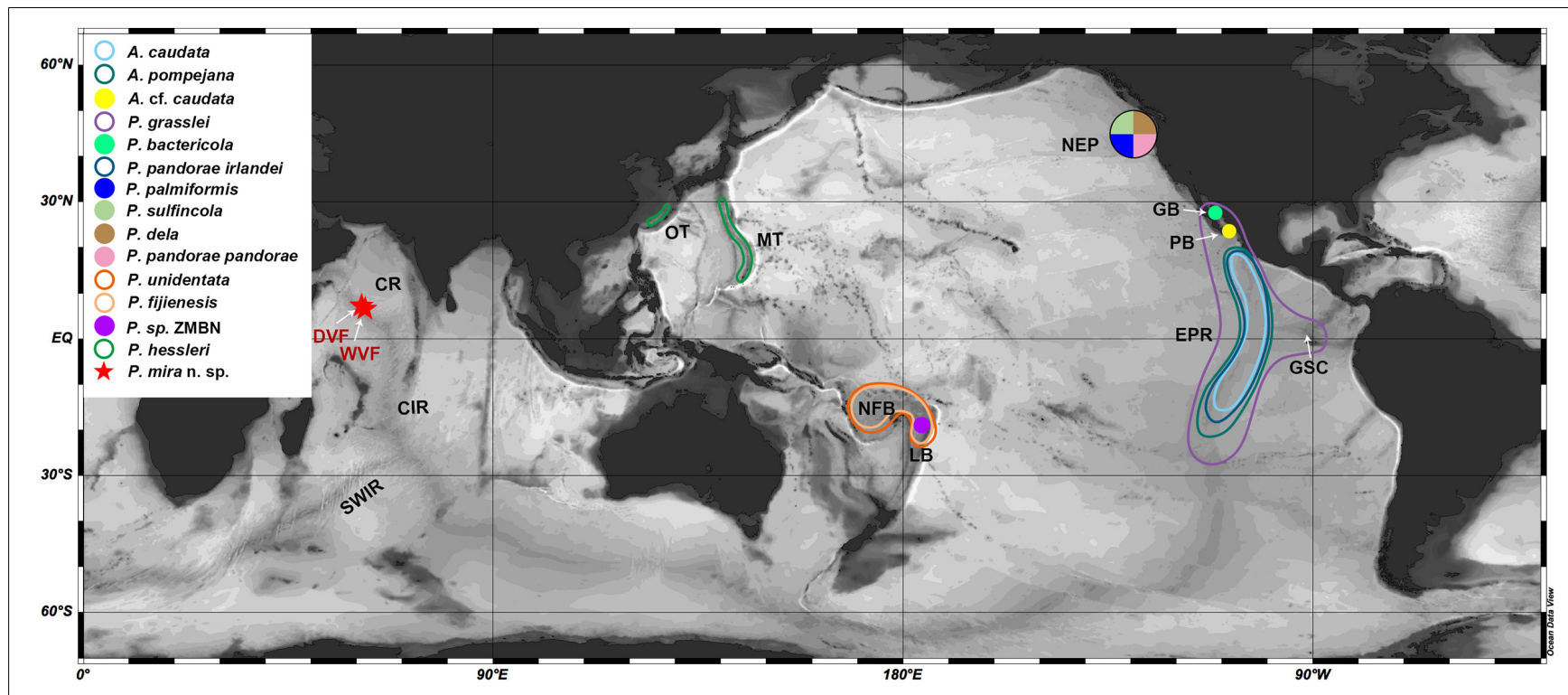

FIGURE 1 | A map showing the known distributions of alvinellids. Specie names coded as different symbol shown in the inset. Abbreviations: DVF, Daxi Vent Field; WVF, Wocan Vent Field; CR, Carlsberg Ridge; CIR, Central Indian Ridge; SWIR, Southwest Indian Ridge; OT, Okinawa Trough; MT, Mariana Trough; NFB, North Fiji back-arc Basin; LB, Lau back-arc Basin; NEP, Northeast Pacific; GB, Guaymas Basin; PB, Pescadero Basin in the southern Gulf of California; EPR, East Pacific Rise; GSC, Galapagos Spreading Center.

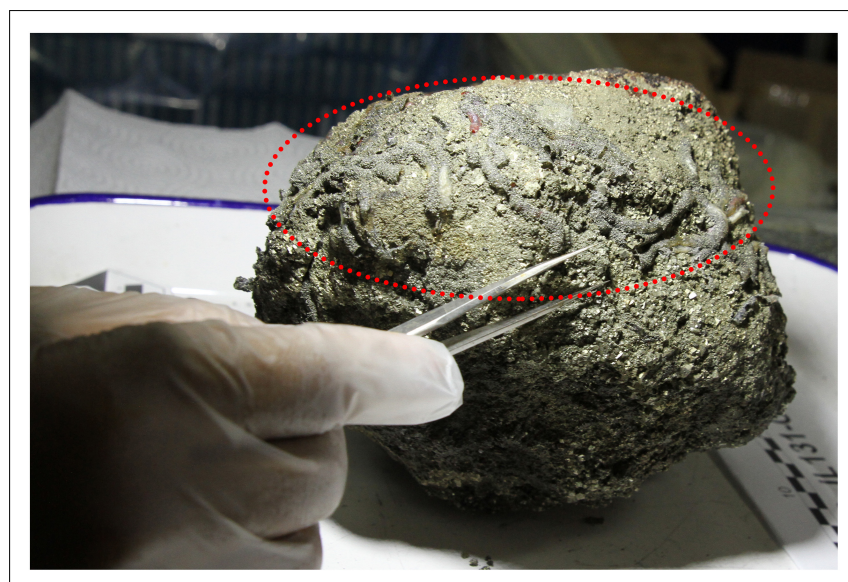

FIGURE 2 | A massive pyrite collected from Wocan field during Jiaolong Dive 131, covered by tubes of Paralvinella mira (circled by red dotted line).

of the Second Institute of Oceanography, Ministry of Natural Resources (MNR), China (RSIO).

\section{Morphology}

All specimens were observed, dissected and photographed under a Zeiss Discovery V.16 stereomicroscope mounted with a CCD camera. Scanning electron microscopic (SEM) images were taken for selected notochaetae and uncini. Samples for SEM were immersed sequentially in a series of mixture of ethanol and Hexamethyldisilizane (HMDS) (1:0, 3:1, 2:2, 1:3, and 0:1 for $30 \mathrm{~min}$ at each step), and then coated in a magnetron sputter
(MSP-1S, Japan) after the HMDS evaporated. Prepared samples were observed using a Hitachi TM-1000 SEM.

\section{Molecular Phylogenetic Analysis}

Genomic DNA extraction of alvinellid tissues (sample ID provided in Table 1) was performed using the DNeasy blood and tissue kit (Qiagen, San Diego, CA, United States) according to a protocol supplied by the manufacturer. Partial gene sequences were amplified using the primer pairs, HCO2198/LCO1490 for c oxidase I (COI) (Folmer et al., 1994), 16Sar/16Sbr for 16S rRNA (Palumbi, 1996), and 18S1.2f/18S9R for $18 \mathrm{~S}$ rRNA (Giribet et al., 1996). Procedures for Polymerase Chain Reaction (PCR), purification and sequencing are as detailed in Zhou et al. (2019). The COI sequences were aligned with the MUSCLE algorithm (Edgar, 2004), and 16S and 18S with MAFFT 7 (Katoh and Standley, 2013) independently. Pairwise $\mathrm{K} 2 \mathrm{P}$ distances based on COI sequences were calculated using MEGA7 (Kumar et al., 2016). The ambiguously aligned regions in each rRNA gene alignment were removed using the online server version of Gblocks under a relaxed condition (Castresana, 2002). SequenceMatrix 1.8 (Vaidya et al., 2011) was used to make a concatenated alignment of the three loci.

Phylogenetic reconstruction of alvinellids was performed on four datasets (each individual gene and their concatenated alignment) using both Bayesian Inference (BI) and Maximum Likelihood (ML) analyses. The substitution models for each of the data partitions were estimated by jModelTest 2.1.10 (Darriba et al., 2012) based on the BIC criteria before phylogenetic analyses, and TIM2 + I + G was selected for COI, TIM2 + G for $16 \mathrm{~S}$ and TIM2ef + I + G for 18S. As TIM2 was not supported in MrBayes, GTR was used instead in both BI and ML analyses. 
TABLE 1 | Sample and sequence information for taxa used in this study.

\begin{tabular}{|c|c|c|c|c|c|c|}
\hline Species & Origin & Sample ID & COI & $16 S$ & $18 S$ & References \\
\hline Alvinella caudata & East Pacific Rise & A1092 & JX423737 & JX423669 & JX423641 & Stiller et al., 2013 \\
\hline Alvinella pompejana & East Pacific Rise & A9429 & AY645983 & MT166794 & MT166855 & Stiller et al., 2020 \\
\hline Alvinella cf. caudata & Gulf of Southern California & - & KY581532 & - & - & Goffredi et al., 2017 \\
\hline Paralvinella grasslei & East Pacific Rise, Guaymas Basin, Galapagos Spreading Center & A1093A & MT167009 & MT166824 & AY577886 & Stiller et al., 2020 \\
\hline Paralvinella palmiformis & Gorda Ridge, Explorer Ridge, Juan de Fuca Ridge, Northeast Pacific & A1104 & MT167010 & MT166825 & AF168747 & Stiller et al., 2020 \\
\hline Paralvinella sulfincola & Gorda Ridge, Explorer Ridge, Juan de Fuca Ridge, Northeast Pacific & - & FJ976042 & FJ976042 & JN936461 & Zhong et al., 2011 \\
\hline Paralvinella hessleri & Okinawa Trough, Mariana Trough, Northwest Pacific & - & MK192098 & MK192098 & - & Wang et al., 2019 \\
\hline Paralvinella fijiensis & North Fiji and Lau Back-Arc Basins, Southwest Pacific & ZMBN 106600 & MG270110 & MG253099 & MG253145 & Eilertsen et al., 2017 \\
\hline Paralvinella pandorae pandorae & Juan de Fuca Ridge, Northeast Pacific & A1105 & DQ270466 & MT166826 & MT166884 & Stiller et al., 2020 \\
\hline Paralvinella sp. ZMBN 106599 & Lau Back-Arc Basin, Southwest Pacific & ZMBN 106599 & MG270111 & MG253100 & MG253146 & Eilertsen et al., 2017 \\
\hline Paralvinella sp. ZMBN 116035 & Lau Back-Arc Basin, Southwest Pacific & ZMBN 116035 & MG270112 & MG253101 & - & Eilertsen et al., 2017 \\
\hline Paralvinella pandorae irlandei & East Pacific Rise & - & - & - & AM159576 & Pradillon et al., 2007 \\
\hline \multirow[t]{9}{*}{ Paralvinella mira } & Wocan, Carlsberg Ridge & $\mathrm{RSIO} 38012$ & MW649793 & MW653274 & MW653276 & This study \\
\hline & Wocan, Carlsberg Ridge & RSIO38101 & MW649801 & MW653275 & MW653277 & This study \\
\hline & Wocan, Carlsberg Ridge & RSIO38104 & MW649794 & - & - & This study \\
\hline & Wocan, Carlsberg Ridge & RSIO38089 & MW649795 & - & - & This study \\
\hline & Wocan, Carlsberg Ridge & RSIO38096 & MW649796 & - & - & This study \\
\hline & Wocan, Carlsberg Ridge & RSIO38088 & MW649797 & - & - & This study \\
\hline & Wocan, Carlsberg Ridge & RSIO38094 & MW649798 & - & - & This study \\
\hline & Wocan, Carlsberg Ridge & $\mathrm{RSIO} 38098$ & MW649799 & - & - & This study \\
\hline & Daxi, Carlsberg Ridge & RSIO38201 & MW649800 & - & - & This study \\
\hline \multicolumn{7}{|l|}{ Outgroup } \\
\hline Amage auricula & & ZMBN 99281 & - & MG253079 & MG253131 & Eilertsen et al., 2017 \\
\hline Grubianella klugei & & ZMBN 95455 & MG270108 & -- & MG253173 & Eilertsen et al., 2017 \\
\hline Amphisamytha marisindica & & RSIO3513 & MN397204 & MN397220 & MN397231 & Zhou et al., 2019 \\
\hline Amphisamytha collaris & & RSIO3520 & MN397209 & MN397225 & MN397233 & Zhou et al., 2019 \\
\hline Amphisamytha jacksoni & & SS15 & JX423758 & JX423675 & JX423646 & Stiller et al., 2013 \\
\hline
\end{tabular}


BI analyses were carried out using MrBayes v3.2 (Ronquist et al., 2011). Four Metropolis-coupled Monte Carlo Markov chains were run for at least 2,000,000 generations until they converged with the Potential Scale Reduction Factor (PSRF) close to 1 (Ronquist et al., 2011). Trees were sampled at every 1000th generation. After discarding the first 25\% initial genealogies, a majority-rule consensus tree was generated for each dataset with the remaining trees. ML analyses were carried out using IQ-TREE 1.6.10 (Trifinopoulos et al., 2016). For each dataset, three replicate runs were performed with the substitution models previously selected by jModelTest, and bootstrap support values determined by the ultrafast bootstrap algorithm for 100,000 replicates. GenBank accession numbers of the sequences used in molecular analyses are provided in Table $\mathbf{1}$.

\section{RESULTS}

\section{Systematics}

Order Terebellida

Family Alvinellidae Desbruyères and Laubier (1986).

Genus Paralvinella Desbruyères and Laubier (1982).

Paralvinella mira n. sp. (Figures 3, 4).

ZooBank registration number: urn:lsid:zoobank.org:act: D2A0F8FC-12B3-4157-A6E9-4ABD665D8333.

\section{Diagnosis}

First three chaetigers not fused; buccal apparatus with a pair of short, strong and acutely pointed tentacles, together with ungrouped slender oral tentacles; notopodia on chaetigers 5 to about 15 (except for chaetiger 7) bearing dorsal digitiform lobe; notochaetae consisting of one long and one short group of chaetae; uncini starting on chaetigers 15-20; Currently only known from northwest Indian Ocean vents.

\section{Type Locality}

Wocan hydrothermal vent field, Carlsberg Ridge, $60.53^{\circ} \mathrm{E} / 6.36^{\circ} \mathrm{N}$, depth $2920 \mathrm{~m}$.

\section{Type Materials}

Holotype (RSIO38206), Wocan hydrothermal vent field $\left(60.53^{\circ} \mathrm{E} / 6.36^{\circ} \mathrm{N}, 2920 \mathrm{~m}\right.$ deep), Carlsberg Ridge, Jiaolong Dive 129, R/V Xiangyanghong 9 cruise DY38-I, March 14, 2017; Paratypes (RSIO38107-38116, 38207, 38208), same for holotype; Paratype (RSIO38204), Wocan field $\left(60.53^{\circ} \mathrm{E} / 6.36^{\circ} \mathrm{N}, 2920 \mathrm{~m}\right.$ deep), Carlsberg Ridge, Jiaolong Dive 125, R/V Xiangyanghong 9 cruise DY38-I, March 4, 2017; Paratypes (RSIO38087-38106), Wocan field $\left(60.53^{\circ} \mathrm{E} / 6.36^{\circ} \mathrm{N}, 2920 \mathrm{~m}\right.$ deep), Carlsberg Ridge, Jiaolong Dive 131, R/V Xiangyanghong 9 cruise DY38-I, March 19, 2017; Paratypes (RSIO38200-38201), Daxi field $\left(60.18^{\circ} \mathrm{E} / 6.80^{\circ} \mathrm{N}, 3450 \mathrm{~m}\right.$ deep), Carlsberg Ridge, Jiaolong Dive 128, R/V Xiangyanghong 9 cruise DY38-I, March 11, 2017. Holotype and all paratypes are deposited in the Repository of the Second Institute of Oceanography, MNR, China (RSIO).

\section{Description}

Body 9.2-20.2 $\mathrm{mm}$ in length (holotype $17.2 \mathrm{~mm}$ ), 0.7-2.5 mm in width (holotype $2.0 \mathrm{~mm}$ ), with 46-62 segments (holotype
60). Body slightly tapered posteriorly (Figures 3A,B). Newly collected specimens reddish, ethanol preserved specimens pale white (Figures 3A,B).

Prostomium with two well developed lateral lobes separated by a deep median incision and enclosing peristomium ventrally (Figures 3C,D). Buccal apparatus complex, bearing a pair of strong and short tapering tentacles; numerous slender grooved oral tentacles inserted on a buccal membrane between the paired strong tentacles; median oral tentacles longer than lateral ones (Figures 3G,H).

First two segment achaetous, fused, clearly discernible ventrally from the next three segments (chaetigers I, II, and III) (Figure 3E). Chaetigers I, II, and III not fused laterally and ventrally, clearly separated from each other (Figure 3E). Anterior chaetigers (first 14-19) with notopodia only.

Branchial region formed by four segments (segment II and chaetigers I, II, and III) (Figure 3D). Branchiae four pairs, in two groups, all similar, pinnate, inflated at base and gradually attenuated (Figures 3A-F,I). Branchial stem strong, tapering distally; secondary filaments numerous, slender, cylindrical, inserted in opposite rows along stem; distal part of stem devoid of gill filaments (Figures 3B,I). Chaetiger 4 with a median dorsal expansion protruding forward and separating the posterior pair of branchiae (Figures 3C,D,F).

Notopodia (except for chaetiger 7), short and cylindrical. First three pairs elevated dorsally, arranged in laterodorsal row, lateral to outermost branchiae (Figures 3C-E); the following notopodia stronger and located more laterally, bearing dorsal digitiform lobe on chaetigers 5 to about 15 (except for chaetiger 7) with the maximum size on chaetiger 8 (Figures $3 \mathbf{A}, \mathbf{C}$ E,J; Figures 4A,B). Chaetiger 7 strongly modified, with only a pair of small notopodial expansion bearing 4-6 strong acicular hooks directed posteriorly (Figure 3J). Notochaetae consisting of one long and one short group, both capillary (Figures $4 \mathrm{~A}-\mathrm{C}$ ); notochaetae hirsute at distal 1/2 part (Figures 4D-F).

Uncinigerous neuropodial tori present on chaetigers from chaetiger 15-20 to the end of body. Uncini numerous, arranged in single rows, with two major teeth in single row above prow, seldom with a small tooth duplicated laterally (Figures 4G,H). Pygidium blunt, smooth, without appendages (Figure 4I).

Tubes whitish, membranous, and covered with mineral granules (Figure 2).

\section{Distribution}

Abundantly found at Wocan hydrothermal vent field on the Carlsberg Ridge, and associated with the "scaly foot" C. squamiferum and Alviniconcha snails at Wocan. Only two specimens were found while washing chimney fragments collected from Daxi.

\section{Etymology}

"Mira" (Latin), wonderful, surprising, named for its unexpected presence at Wocan field in high abundance.

\section{Remarks}

The assignment of P. mira n. sp. in Paralvinella is supported by its morphological concordance with the diagnosis of the subgenus 

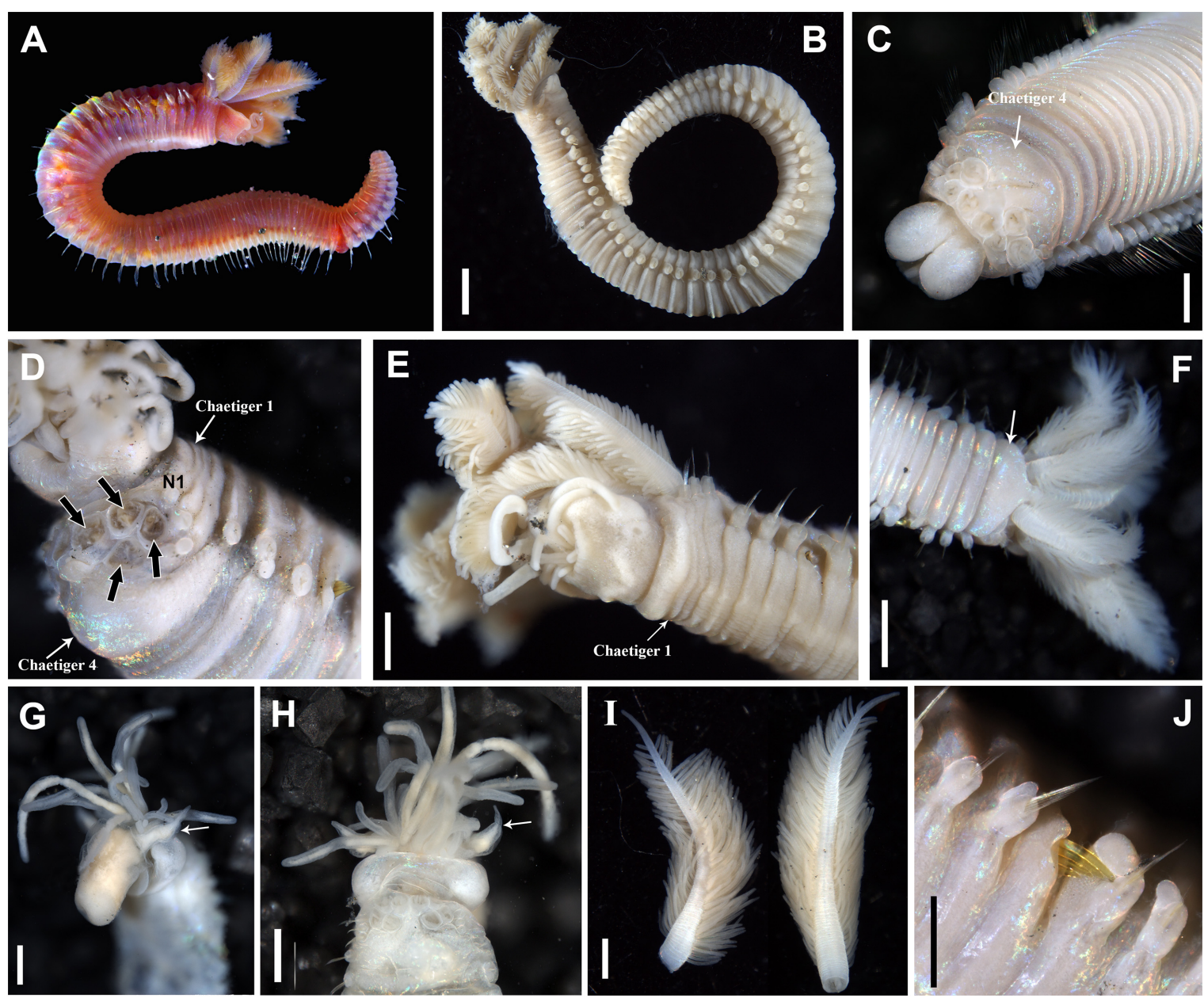

FIGURE 3 | Paralvinella mira n. sp. (A) Paratype (RSIO38207) before fixation, lateral view; (B) Holotype (RSIO38206), lateral view; (C) Paratype (RSIO38087), anterior part, dorsal view, with branchiae removed; (D) Paratype (38204), anterior part, dorsal lateral view, showing arrangement of branchiae (black arrows bordered by white) in relation to the first several segments, N1, notopodium on chaetiger 1; (E) Holotype (RSIO38206), anterior part, ventral lateral view; (F) Paratype (RSIO38087), anterior part, dorsal view; (G) Paratype (RSIO38106), buccal apparatus everted, showing the short, strong and pointed tentacle (white arrow), anterior view; (H) Paratype (RSIO38106), buccal apparatus everted, showing the short, strong and pointed tentacle (white arrow), dorsal view; (I) Branchiae with distal parts devoid of filaments; (J) Notopodia on chaetigers 5-9, showing modified notopodia on chaetiger 7. Scale bar: (B,D,F), 1 mm; (C,E,G-J), 0.5 mm.

Miralvinella: (1) complex buccal apparatus with paired large tentacles in males and numerous grooved oral tentacles inserted on the buccal membrane; (2) four pairs of pinnate branchiae with cylindrical filaments located on opposite areas along the stem; (3) notopodia on some anterior chaetigers (except for chaetiger 7) bearing digitiform notopodial lobes; (4) uncini starting on segments well after chaetiger 7 (Desbruyères and Laubier, 1993; Jollivet and Hourdez, 2020).

Three species have been placed in Miralvinella, Paralvinella (Miralvinella) dela Detinova (1988), Paralvinella (Miralvinella) bactericola Desbruyères and Laubier and Paralvinella (Miralvinella) hessleri Desbruyères and Laubier (1989), with P. hessleri being most similar to P. mira n. sp. according to the morphology of the branchiae and buccal apparatus. However, the new species can be distinguished from these three Miralvinella species in that its first three chaetigers are not fused, which can be easily examined from lateral and ventral view under a stereomicroscope. The new species is further different from $P$. hessleri in locating oral tentacles directly on the buccal membrane instead of paired quadrilobed upper lips in the latter (Desbruyères and Laubier, 1989), and from P. bactericola and $P$. dela in the position of the first uncinigerous neuropodial tori (chaetiger 16 vs. 32) (Desbruyères and Laubier, 1991; Detinova, 1988).

\section{Molecular Analyses}

Paralvinella mira forms a distinct lineage based either on pairwise COI distance or phylogenetic inference using the four sequence datasets (Supplementary Table 1, Figure 5, and Supplementary Figures 1-3). The new species showed lowest genetic distance with Paralvinella sp. ZMBN (sensu Eilertsen et al., 2017) from southwest Pacific (pairwise COI K2P distance 12.3\%), falling within the range of pairwise divergence between other alvinellid 

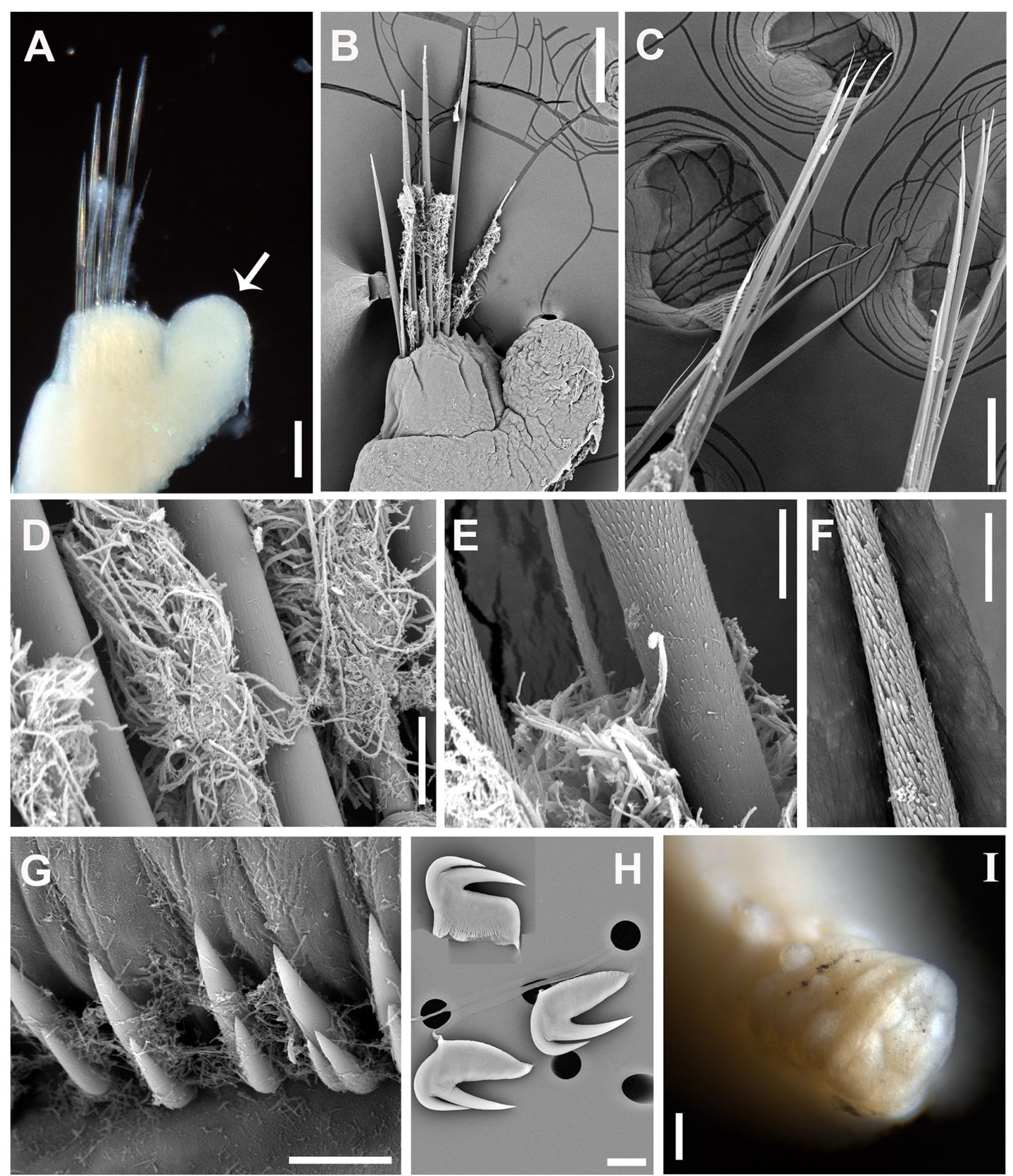

FIGURE 4 | Paralvinella mira n. sp. (A) Notopodia on segment 9, white arrow indicating the digitiform notopodial lobe, anterior view; (B) SEM. Notopodia on segment 9, anterior view; (C) SEM. Notochaetae on segments chaetigers 35-37; (D) SEM. Basal part of notochaetae; (E) SEM. Middle part of notochaetae; (F) SEM. Distal part of notochaetae; (G) SEM. Uncinigerous torus; (H) SEM. Three uncini in details; (I) Pygidium. Scale bar: (A-C,I), $100 \mu \mathrm{m}$; (D-H), $10 \mu \mathrm{m}$.

species (range 6.2-26.6\%) but much higher than the intraspecific values $(\sim 0.2 \%$, Supplementary Table 1$)$. No genetic divergence was found between the Daxi (RSIO38201) and the Wocan individuals (range $0-0.6 \%$ ).

Based on concatenated alignments of the three genes, both $\mathrm{BI}$ and $\mathrm{ML}$ analyses reconstruct trees with topology similar to that of a previous study (Figure 5; Stiller et al., 2020). The Alvinellidae forms a monophyletic group with high support (Bayesian posterior probabilities, PP/ML bootstrap value, BP: 1/100), with $P$. pandorae species complex (clade I, PP/BP: 1/98) being sister to a larger clade comprising a monophyletic Alvinella clade (clade II, PP/BP: 1/100) and its sister clade of the remaining 


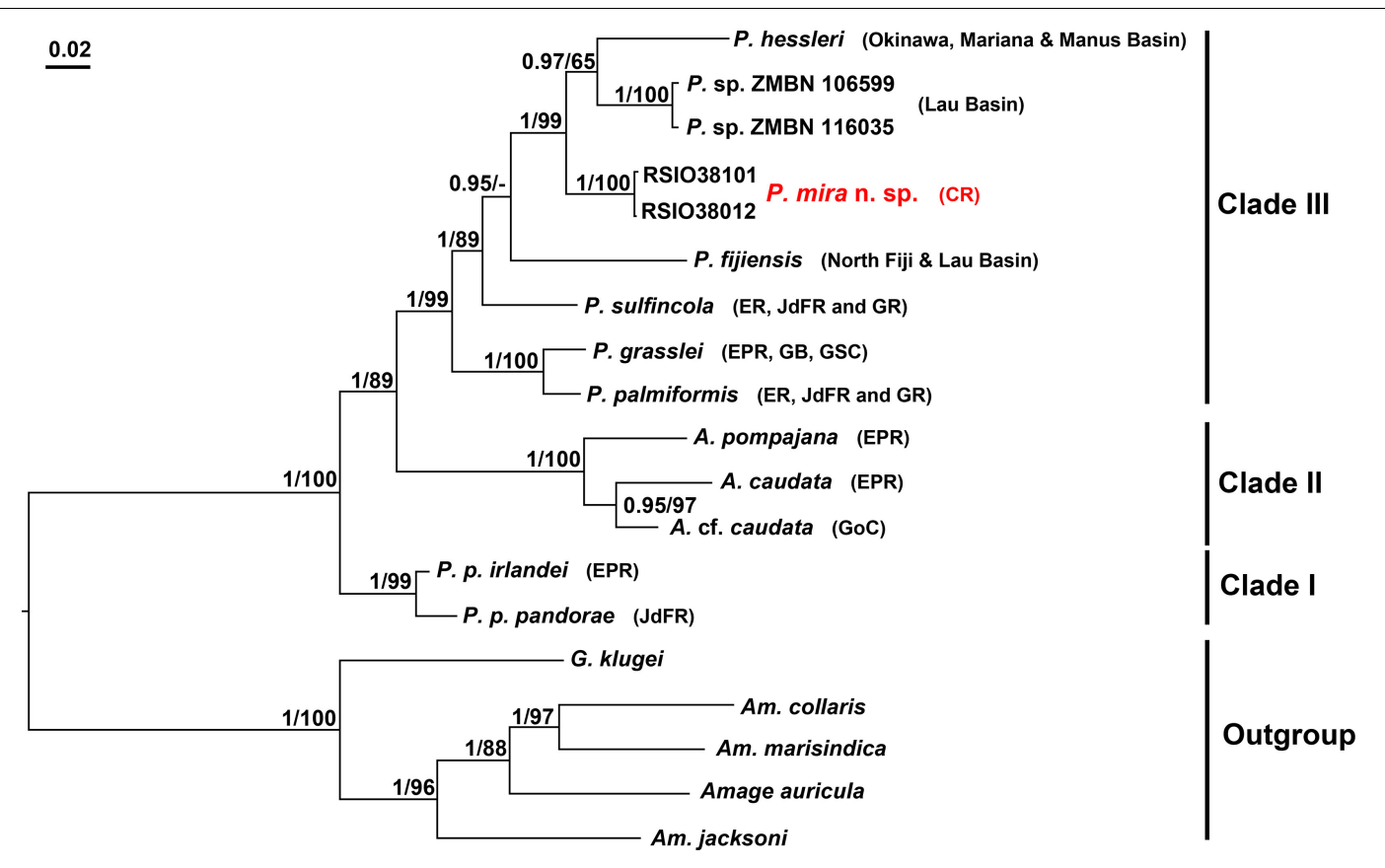

FIGURE 5 | Phylogenetic reconstruction of alvinellids based on the concatenated alignments of COI, $16 \mathrm{~S}$ and $18 \mathrm{~S}$ using $\mathrm{BI}$ and $\mathrm{ML}$ analyses, imposed on the consensus BI tree. Node supports are given as PP/BS. Nodes that are not recovered in ML analyses are denoted as "-"; The new species, P. mira n. sp. is shown in red. Abbreviations: A., Alvinella; Am., Amphisamytha; G., Grubianella; P., Paralvinella; P. p., Paralvinella pandorae. Accession numbers of the sequences used are provided in Table 1.

Paralvinella species (clade III, PP/BP: 1/99). P. grasslei and $P$. palmiformis form a well-supported subclade within clade III (PP/BP: 1/100) (Figure 5). Each gene tree reveals topology similar to the above-mentioned pattern, but with lower supports (Figure 5 and Supplementary Figures 1-3).

The Indian Ocean species, $P$. mira falls into clade III with strong support (PP/BP: 1/98) and grouped with the West Pacific species ( $P$. hessleri from northwest Pacific and Paralvinella sp. ZMBN from southwest Pacific vents), resulting in an Indian/West Pacific subclade (Figure 5). The clustering of the Indian and West Pacific species is recovered in $16 \mathrm{~S}$ and $18 \mathrm{~S}$ gene trees with lower supports, and the topology within clade III is poorly resolved in the COI gene tree (Figure 5 and Supplementary Figures 1-3).

\section{DISCUSSION}

In the present study, we described a new species of Alvinellidae from northern Indian Ocean hydrothermal vent field and confirmed its placement in the genus Paralvinella using both morphological and genetic evidences. The concatenated phylogeny revealed a branch pattern of three clades (clades I, II, and III in Figure 5) similar to other gene trees, but with higher supports. This three-clades pattern is also largely the same with that recovered in Stiller et al. (2020) except for the positions of $P$. sulfincola and $P$. fijiensis in relation to other species in clade III. The subdivision of Paralvinella into three subgenera was proposed by Desbruyères and Laubier (1993) based on traits of branchiae filaments, buccal apparatus, and distributions of the notopodial lobes and the uncinigerous tori (Jollivet and Hourdez, 2020). The subgenus Nautalvinella matches well with Clade I and was referred to Nautalvinella Desbruyères and Laubier (1993) (Stiller et al., 2020), but Paralvinella (Nautalvinella) unidentata is not clustered with this clade in an ultrametric phylogenomic tree recently reconstructed by Jollivet and Hourdez (2020). Similarly, monophyletic cluster of the four Paralvinella (Paralvinella) species (as revealed in Stiller et al., 2020 and Jollivet and Hourdez, 2020) in clade III is likely to be unstable with the addition of the Indian and West Pacific species in the present study. It is currently not possible to determine if the Indian/West Pacific subclade (formed by $P$. hessleri, Paralvinella sp. ZMBN and P. mira) corresponds to the subgenus Miralvinella due to the lack of morphological data from Paralvinella sp. ZMBN, on one hand, and DNA data from $P$. bactericola and $P$. dela, on the other hand. Thus, a wider sampling effort on either taxa or DNA markers is needed to validate the delineation of these species at subgenus level.

The Indian Ocean alvinellids appear to be genetically closer to the West Pacific rather than to the East Pacific counterparts based on either genetic distance calculation or phylogeny inference. Genetic affiliations between Indian and West Pacific counterparts have been shown in a variety of taxa for the vent fauna, such as Bathymodiolus mussels (Breusing et al., 2015), Alviniconcha snails (Johnson et al., 2015), Amphisamytha (Zhou et al., 2019), Archinome jasoni (Borda et al., 2013), resulting in a hypothesis of historical connection between the two regions (Watanabe and Beedessee, 2015). By contrast, two other Wocan polychaetes, Amphisamytha wocanensis (Ampharetidae) 
and Hesiolyra heteropoda (Hesionidae), temporally exhibit closer genetic relationships with their East Pacific congeners (Zhou et al., 2019; Wang et al., 2020). Although the phylogenetic inference may be modified with the addition of either more DNA markers or more sampling taxa in future, the current results indicate invasion of Paralvinella into northern Indian Ocean from the West Pacific. According to the current phylogeny, the emergence of the West Pacific alvinellid lineages appears to be more recently than their East Pacific relatives, and the latter also exhibit highest phylogenetic diversity (Jollivet and Hourdez, 2020; Stiller et al., 2020). This pattern is closer to the scenario proposed by Bachraty et al. (2009), in which EPR played a central role in the dissemination of vent fauna, although Moalic et al. (2012) tended to put the West Pacific in the central position connecting the other vent fauna provinces. In addition, due to the lack of information on the alvinellid worms collected at the Solitaire vent field on the CIR, we still do not know whether the colonization of the Indian ridge by the Western Pacific alvinellids occurred once or via two independent events.

Whatever the route taken by the ancestors of $P$. mira to invade the Indian Ocean, this invasion event has undoubtedly changed our view of vent polychaete biogeography in the Indian Ocean. The discovery of $P$. mira adds to the unique polychaete diversity at northern Indian Ocean hydrothermal vents. Together with the observation of alvinellid worms at the Solitaire vent field, this worm family appears to be absent from all well-characterized hydrothermal vents south of Solitaire, including Edmond, Kairei, Tiancheng, and Longqi (Watanabe and Beedessee, 2015; Copley et al., 2016; Zhou et al., 2018; Gerdes et al., 2019). Notably, distinct dominant polychaete assemblages are recovered at vents across the Indian Ocean Ridges: dorvillids/ampharetids/hesionids at Longqi (on the SWIR, Zhang et al., 2017; Zhou et al., 2018; Wang et al., 2020), amphinomids at Kairei (on the CIR, Watanabe and Beedessee, 2015), and alvinellids/hesionids at Wocan (on the CR, Wang et al., 2020; this study). These differences together with the observed variations of faunal composition on crustaceans and mollusks (the other two dominant taxa in deep-sea hydrothermal vents), result in a high faunal dissimilarity between the SWIR and CIR vent communities and indicate two potential subbioregions (Zhou et al., 2018; Sun et al., 2020). As one of the three dominant taxa, the specific polychaete assemblage at the Wocan field reinforces such dissimilarities between CR and CIR/SWIR vent communities and strengthens the point of view that the northern Indian hydrothermal vents may hold a unique biodiversity. This provides new insights toward biogeographic subdivision in the Indian Ocean.

\section{REFERENCES}

Bachraty, C., Legendre, P., and Desbruyeres, D. (2009). Biogeographic relationships among deep-sea hydrothermal vent faunas at global scale. Deep-Sea Res. Part I 56, 1371-1378. doi: 10.1016/j.dsr.2009.01. 009

Borda, E., Kudenov, J. D., Chevaldonné, P., Blake, J. A., Desbruyères, D., Fabri, M.C., et al. (2013). Cryptic species of Archinome (Annelida: Amphinomida) from vents and seeps. Proc. R. Soc. Lond. B 280:20131876. doi: 10.1098/rspb.2013. 1876

\section{DATA AVAILABILITY STATEMENT}

The datasets presented in this study can be found in online repositories. The names of the repository/repositories and accession number(s) can be found in the article.

\section{AUTHOR CONTRIBUTIONS}

$\mathrm{YZ}$ and CW designed the project. YZ collected and preserved the samples. $\mathrm{YH}$ and $\mathrm{YZ}$ performed the morphological examination and molecular analyses. All authors drafted the manuscript and contributed to the final version.

\section{FUNDING}

This work was financially supported by China Ocean Mineral Resources R\&D Association (Grant No. DY135-E2-1-02 and DY135-S2-01-07), the Scientific Research Fund of the Second Institute of Oceanography, MNR (Grant No. QNYC1902), and the National Natural Science Foundation of China (NSFC) (Grant No. 91951201). Cruise DY38 was supported by China Ocean Mineral Resources R\&D Association (No. DYHC-135-38).

\section{ACKNOWLEDGMENTS}

We are grateful to all the crew and scientists onboard the $\mathrm{R} / \mathrm{V}$ Xiangyanghong 9 and the pilot/team of the HOV Jiaolong during cruise DY38. We would like to give special thanks to Xiqiu Han, the chief scientist of cruise DY38 for her design and execution of the cruise, Didier Jollivet for sharing his expertise on the alvinellid worms, Yejian Wang for his help on specimens sorting, Zipan Wang for taking pictures of samples onboard, and the three reviewers for their valuable comments to improve the manuscript.

\section{SUPPLEMENTARY MATERIAL}

The Supplementary Material for this article can be found online at: https://www.frontiersin.org/articles/10.3389/fmars. 2021.669918/full\#supplementary-material

Breusing, C., Johnson, S. B., Tunnicliffe, V., and Vrijenhoek, R. C. (2015). Population structure and connectivity in Indo-Pacific deep-sea mussels of the Bathymodiolus septemdierum complex. Conserv. Genet. 16, 1415-1430. doi: 10.1007/s10592-015-0750-750

Castresana, J. (2002). Gblocks Server. Available online at: http://molevol.cmima. csic.es/castresana/Gblocks_server.html (accessed January 19, 2021).

Chen, C., Linse, K., Copley, J. T., and Rogers, A. D. (2015). The 'scaly-foot gastropod': A new genus and species of hydrothermal vent-endemic gastropod (neomphalina: peltos-piridae) from the indian ocean. J. Mollus. Stud. 81, 322-334. doi: 10.1093/mollus/eyv013. 
Copley, J. T., Marsh, L., Glover, A. G., Huhnerbach, V., Nye, V. E., Reid, W. D. K., et al. (2016). Ecology and biogeography of megafauna and macrofauna at the first known deep-sea hydrothermal vents on the ultraslow-spreading southwest indian ridge. Sci. Rep. 6:13. doi: 10.1038/srep39158.

Darriba, D., Taboada, G. L., Doallo, R., and Posada, D. (2012). jModelTest 2: more models, new heuristics and parallel computing. Nat. Methods 9:772. doi: 10.1038/nmeth.2109

Desbruyères, D., Alayse-Danet, A. M., Ohta, S., and The Scientific Parties of Biolau, and Starmer Cruises (1994). Deep-sea hydrothermal communities in southwestern Pacific back-arc basins (the North Fiji and Lau Basins): composition, microdistribution and food web. Mar. Geol. 116, 227-242. doi: 10.1016/0025-3227(94)90178-3

Desbruyères, D., and Laubier, L. (1980). Alvinella pompejana gen. sp. nov., Ampharetidae aberrant des sources hydrothermales de la ride East-Pacifique. Oceanol. Acta 3, 267-274.

Desbruyères, D., and Laubier, L. (1982). Paralvinella grasslei, new species of Alvinellinae (Polychaeta: Ampharetidae) from the Galapagos Rift geothermal vents. Proc. Biol. Soc. Wash. 95, 484-494.

Desbruyères, D., and Laubier, L. (1986). Les Alvinellidae. Une famille nouvelle d'anneilides polycheİtes infeìodeìes aux sources hydrothermales sous-marines: systeìmatique, biologie et eìcologie. Can. J. Zool. 64, 2227-2245. doi: 10.1139/ z86-337

Desbruyères, D., and Laubier, L. (1989). Paralvinella hessleri, new species of Alvinellidae (Polychaeta) from the Mariana back-arc basin hydrothermal vents. Proc. Biol. Soc. Wash. 102, 761-767.

Desbruyères, D., and Laubier, L. (1991). Systematics, phylogeny, ecology and distribution of the Alvinellidae (Polychaeta) from deep-sea hydrothermal vents. Ophelia 5, 31-45.

Desbruyères, D., and Laubier, L. (1993). New species of Alvinellidae (Polychaeta) from the North Fiji back-arc basin hydrothermal vents (southwestern Pacific). Proc. Biol. Soc. Wash. 106, 225-236.

Detinova, N. N. (1988). New species of polychaetous annelids from hydrothermal vents of the Juan de Fuca Ridge (Pacific Ocean). Zoologichesky Zhurnal 57, $858-864$.

Edgar, R. C. (2004). MUSCLE: multiple sequence alignment with high accuracy and high throughput. Nucleic Acids Res. 32, 1792-1797. doi: 10.1093/nar/gkh340

Eilertsen, M. H., Kongsrud, J. A., Alvestad, T., Stiller, J., Rouse, G. W., and Rapp, H. T. (2017). Do ampharetids take sedimented steps between vents and seeps? Phylogeny and habitat-use of Ampharetidae (Annelida, Terebelliformia) in chemosynthesis-based ecosystems. BMC Evol. Biol. 17:222. doi: 10.1186/ s12862-017-1065-1061

Folmer, O., Black, M., Hoeh, W., Lutz, R., and Vrijenhoek, R. (1994). DNA primers for amplification of mitochondrial cytochrome $\mathrm{c}$ oxidase subunit I from diverse metazoan invertebrates. Mol. Mar. Biol. Biotechnol. 3, 294-299.

Gerdes, K., Martiìnez Arbizu, P., Schwarz-Schampera, U., Schwentner, M., and Kihara, T. C. (2019). Detailed mapping of hydrothermal vent fauna: a 3D reconstruction approach based on video imagery. Front. Mar. Sci. 6:96. doi: 10.3389/fmars.2019.00096

Giribet, G., Carranza, S., Baguna, J., Riutort, M., and Ribera, C. (1996). First molecular evidence for the existence of a Tardigrada+Arthropoda clade. Mol. Biol. Evol. 13, 76-84. doi: 10.1093/oxfordjournals.molbev.a025573

Goffredi, S. K., Johnson, S., Tunnicliffe, V., Caress, D., Clague, D., Escobar, E., et al. (2017). Hydrothermal vent fields discovered in the southern Gulf of California clarify role of habitat in augmenting regional diversity. Proc. R. Soc. B 284:20170817. doi: 10.1098/rspb.2017.0817

Hurtado, L. A., Lutz, R. A., and Vrijenhoek, R. C. (2004). Distinct patterns of genetic differentiation among annelids of eastern Pacific hydrothermal vents. Mol. Ecol. 13, 2603-2615. doi: 10.1111/j.1365-294x.2004.02287.x

Johnson, S. B., Warén, A., Tunnicliffe, V., Van Dover, C. L., Geoffrey Wheat, C., Schultz, T. F., et al. (2015). Molecular taxonomy and naming of five cryptic species of Alviniconcha snails (Gastropoda: Abyssochrysoidea) from hydrothermal vents. Syst. Biodivers. 13, 278-295. doi: 10.1080/14772000.2014. 970673

Jollivet, D., Desbruyères, D., Ladrat, C., and Laubier, L. (1995). Evidence for differences in allozyme thermostability in deep-sea hydrothermal vent polychaetes Alvinellidae: a possible selection by habitat. Mar. Ecol. Prog. Ser. 123, 125-136. doi: 10.3354/meps 123125
Jollivet, D., and Hourdez, S. (2020). “Alvinellidae Desbruyères \& Laubier, 1986,” in Handbook of Zoology - Annelida. Wilfried Westheide, Günter Purschke \& Markus Böggemann, Vol. 3, eds I. I. I. Sedentaria and I. Errantia (Berlin: Walter de Gruyter GmbH), 145-162. doi: 10.1515/9783110291704-007

Katoh, K., and Standley, D. M. (2013). MAFFT multiple sequence alignment software version 7: improvements in performance and usability. Mol. Biol. Evol. 30, 772-780. doi: 10.1093/molbev/mst010

Kumar, S., Stecher, G., and Tamura, K. (2016). MEGA7: molecular evolutionary genetics analysis version 7.0 for Bigger Datasets. Mol. Biol. Evol. 33, 1870-1874. doi: 10.1093/molbev/msw054

Moalic, Y., Desbruyères, D., Duarte, C. M., Rozenfeld, A. F., Bachraty, C., and Arnaud-Haond, S. (2012). Biogeography revisited with network theory: retracing the history of hydrothermal vent communities. Syst. Biol. 61, 127-137. doi: 10.1093/sysbio/syr088

Nakamura, K., Watanabe, H., Miyazaki, J., Takai, K., Kawagucci, S., Noguchi, T., et al. (2012). Discovery of new hydrothermal activity and chemosynthetic fauna on the central indian ridge at 186 degrees-206 degrees S. PLoS One 7:e32965. doi: 10.1371/journal.pone.0032965

Palumbi, S. R. (1996). "Nucleic acids II: the polymerase chain reaction," in Molecular Systematics. Sinauer Associates, eds D. M. Hillis, C. Moritz, and B. K. Mable (Sunderland, MA: APA), 205-247.

Pradillon, F., Schmidt, A., Peplies, J., and Dubilier, N. (2007). Species identification of marine invertebrate early stages by whole-larvae in situ hybridisation of $18 \mathrm{~S}$ ribosomal RNA. Mar. Ecol. Prog. Ser. 333, 103-116. doi: 10.3354/meps333103

Rogers, A. D., Tyler, P. A., Connelly, D. P., Copley, J. T., James, R., Larter, R. D., et al. (2012). The discovery of new deep-sea hydrothermal vent communities in the southern ocean and implications for biogeography. PLoS Biol. 10:e1001234. doi: 10.1371/journal.pbio.1001234

Ronquist, F., Teslenko, M., Van der Mark, P., Ayres, D. L., Darling, A., Höhna, S., et al. (2011). MrBayes 3.2: efficient Bayesian phylogenetic inference and model choice across a large model space, systematic biology. Syst. Biol. 61, 539-542. doi: 10.1093/sysbio/ sys029

Stiller, J., Rousset, V., Pleijel, F., Chevaldonné, P., Vrijenhoek, R. C., and Rouse, G. W. (2013). Phylogeny, biogeography and systematics of hydrothermal vent and methane seep Amphisamytha (Ampharetidae, Annelida), with descriptions of three new species. Syst. Biodivers. 11, 35-65. doi: 10.1080/14772000.2013. 772925

Stiller, J., Tilic, E., Rousset, V., Pleijel, F., and Rouse, G. W. (2020). Spaghetti to a tree: a robust phylogeny for Terebelliformia (Annelida) based on transcriptomes, molecular and morphological data. Biology 9, 1-29. doi: 10. 3390/biology9040073

Sun, J., Zhou, Y., Chen, C., Kwan, Y. H., Sun, Y., Wang, X., et al. (2020). Nearest vent, dearest friend: biodiversity of Tiancheng vent field reveals cross-ridge similarities in the Indian Ocean. R. Soc. open sci. 7:200110. doi: 10.1098/rsos. 200110

Trifinopoulos, J., Nguyen, L. T., von Haeseler, A., and Minh, B. Q. (2016). W-IQTREE: a fast online phylogenetic tool for maximum likelihood analysis. Nucleic Acids Res. 44, W232-W235. doi: 10.1093/nar/gkw256

Tunnicliffe, V., Desbruyères, D., Jollivet, D., and Laubier, L. (1993). Systematic and ecological characteristics of Paralvinella sulfincola Desbruyères and Laubier, a new polychaete (family Alvinellidae) from northeast Pacific hydrothermal vents. Can. J. Zool. 71, 286-297. doi: 10.1139/z93-041

Vaidya, G., Lohman, D. J., and Meier, R. (2011). SequenceMatrix: concatenation software for the fast assembly of multi-gene datasets with character set and codon information. Cladistics 27, 171-180. doi: 10.1111/j.1096-0031.2010. 00329.x

Van Dover, C. L. (2000). The Ecology of Deep-Sea Hydrothermal Vents. Princeton: Princeton University Press.

Van Dover, C. L., Humphris, S. E., Fornari, D., Cavanaugh, C. M., Collier, R., Goffredi, S. K., et al. (2001). Biogeography and ecological setting of Indian Ocean hydrothermal vents. Science 294, 818-823. doi: 10.1126/science.1064574

Vrijenhoek, R. C. (2013). On the instability and evolutionary age of deep-sea chemosynthetic communities. Deep Sea Res. Part II 92, 189-200. doi: 10.1016/ j.dsr2.2012.12.004

Wang, Y., Han, X., Petersen, S., Frische, M., Qiu, Z., Li, H., et al. (2017). Mineralogy and trace element geochemistry of sulfide minerals from the Wocan Hydrothermal Field on the slow-spreading Carlsberg Ridge. Indian Ocean. Ore Geol. Rev. 84, 1-19. doi: 10.1016/j.oregeorev.2016.12.020 
Wang, Y., Han, X., Zhou, Y., Qiu, Z., Yu, X., Petersen, S., et al. (2021). The daxi vent field: an active mafic-hosted hydrothermal system at a non-transform offset on the slow-spreading Carlsberg Ridge, $6^{\circ} 48^{\prime} \mathrm{N}$. Ore Geol. Rev. 129:103888. doi: 10.1016/j.oregeorev.2020.10 3888

Wang, Z., Xu, T., Zhang, Y., Zhou, Y., Liu, Z., Chen, C., et al. (2020). Molecular phylogenetic and morphological analyses of the 'monospecific' Hesiolyra (Annelida: Hesionidae) reveal two new species. Deep Sea Res. Part I 166, 1-14. doi: 10.1016/j.dsr.2020.103401

Wang, H., Zhang, H., Wang, M., Chen, H., Lian, C., and Li, C. (2019). The complete mitochondrial genome of Paralvinella hessleri: an endemic species of deep-sea hydrothermal vent. Mitochondrial DNA B. 4, 832-833. doi: 10.1080/23802359. 2019.1567289

Watanabe, H., and Beedessee, G. (2015). "Vent fauna on the central indian ridge," in Subseafloor Biosphere Linked to Hydrothermal Systems: TAIGA Concept, eds J.-I. Ishibashi, K. Okino, and M. Sunamura (Tokyo: Springer Japan), 205-212. doi: 10.1007/978-4-431-54865-2_16

Wolff, T. (2005). Composition and endemism of the deep-sea hydrothermal vent fauna. Cahiers de Biol. Mar. 46, 97-104. doi: 10.1007/978-3-319-45340-8_4

Zhang, D., Zhou, Y., Wang, C., and Rouse, G. W. (2017). A new species of ophryotrocha (Annelida, Eunicida, Dorvilleidae) from hydrothermal vents on the southwest indian ridge. ZooKeys 687, 1-9. doi: 10.3897/zookeys.687. 13046

Zhong, M., Hansen, B., Nesnidal, M., Golombek, A., Halanych, K. M. and Struck, T. H. (2011). Detecting the symplesiomorphy trap: a multigene phylogenetic analysis of terebelliform annelids. BMC Evol. Biol. 11:369. doi: 10.1186/14712148-11-369

Zhou, Y., Chen, C., Sun, Y., Watanabe, H. K., Zhang, R., and Wang, C. (2019). Amphisamytha (Annelida: Ampharetidae) from Indian Ocean hydrothermal vents: biogeographic implications. Deep Sea Res. Part I 154, 1-12. doi: 10.1016/ j.dsr.2019.103148

Zhou, Y., Zhang, D., Zhang, R., Liu, Z., Tao, C., Lu, B., et al. (2018). Characterization of vent fauna at three hydrothermal vent fields on the Southwest Indian Ridge: implications for biogeography and interannual dynamics on ultraslow-spreading ridges. Deep Sea Res. Part I 137, 1-12. doi: 10.1016/j.dsr.2018.05.001

Conflict of Interest: The authors declare that the research was conducted in the absence of any commercial or financial relationships that could be construed as a potential conflict of interest.

The handling editor declared a past co-authorship with several of the authors DZ, CW, and YZ.

Copyright (c) 2021 Han, Zhang, Wang and Zhou. This is an open-access article distributed under the terms of the Creative Commons Attribution License (CC BY). The use, distribution or reproduction in other forums is permitted, provided the original author(s) and the copyright owner(s) are credited and that the original publication in this journal is cited, in accordance with accepted academic practice. No use, distribution or reproduction is permitted which does not comply with these terms. 